Review

\title{
Potential Benefits of Nrf2/Keap1 Targeting in Pancreatic Islet Cell Transplantation
}

\author{
Alberto Jarrin Lopez, Hien Lau, Shiri Li and Hirohito Ichii * \\ Department of Surgery, University of California, Irvine, CA 92868, USA; ajarrinl@uci.edu (A.J.L.); \\ hlau2@uci.edu (H.L.); shiril@uci.edu (S.L.) \\ * Correspondence: hichii@uci.edu
}

Received: 15 March 2020; Accepted: 14 April 2020; Published: 16 April 2020

\begin{abstract}
Permanent pancreatic islet cell destruction occurs in type 1 diabetes mellitus (T1DM) through the infiltration of inflammatory cells and cytokines. Loss of $\beta$-cell integrity secondary to oxidation leads to an inability to appropriately synthesize and secrete insulin. Allogenic islet cell transplantation (ICT) has risen as a therapeutic option to mitigate problematic hypoglycemia. Nevertheless, during the process of transplantation, islet cells are exposed to oxidatively caustic conditions that severely decrease the islet cell yield. Islet cells are at a baseline disadvantage to sustain themselves during times of metabolic stress as they lack a robust anti-oxidant defense system, glycogen stores, and vascularity. The Nrf2/Keap1 system is a master regulator of antioxidant genes that has garnered attention as pharmacologic activators have shown a protective response and a low side effect profile. Herein, we present the most recently studied Nrf2/Keap1 activators in pancreas for application in ICT: Dh404, dimethyl fumarate (DMF), and epigallocatechin gallate (EGCG). Furthermore, we discuss that Nrf2/Keap1 is a potential target to ameliorate oxidative stress at every step of the Edmonton Protocol.
\end{abstract}

Keywords: Nrf2/Keap1; antioxidant; diabetes; pancreatic islet; transplantation

\section{Introduction}

Type 1 diabetes mellitus (T1DM) leads to permanent pancreatic islet cell destruction via the infiltration of inflammatory cells and cytokines [1,2]. T1DM typically occurs in children and adolescents that have a genetic predisposition and have experienced an environmental stressor (i.e., virus or toxin) [3,4]. Under physiological conditions, $\beta$-cells elegantly uptake and convert glucose into ATP, stimulating ion gradients that drive the depolarization-dependent release of insulin. Loss of $\beta$-cell integrity leads to an inability to appropriately synthesize and secrete the peptide hormone. This is caustic metabolically, as the tissues are unable to meet their energy demands. In the United States, an estimated 30.3 million people of all ages had diabetes in 2015 [5], with approximately $5 \%$ of these having T1DM. Within those 30.3 million, it was estimated that 17,900 were children or adolescents younger than 20 years of age [5]. While the majority of diabetes cases are type 2 diabetes mellitus (T2DM), late-term T2DM is functionally equivalent to T1DM [6,7]. Allogenic islet cell transplantation (ICT) has thus risen as a therapeutic option to mitigate problematic hypoglycemia [8]. Following the Edmonton protocol, islet cells are procured from cadaveric donors and perfused into the hepatic portal vein [9].

Islet cells are at a baseline disadvantage as they lack a robust anti-oxidant defense system. In fact, relative to other tissues in the rat model, islet cells contain significantly less glutathione peroxidase, superoxide dismutase, and catalase $[10,11]$. The cells' ability to combat oxidative stress is the key for remaining functional as reactive oxygen species (ROS) directly impact the integrity of the $\beta$-cell at the biomolecular level [12]. Higher sensitivity to stress along with pancreatic islet during isolation, 
preparation, and reperfusion-related injuries set the islet cells for engraftment and survival failure. It is no surprise then that the five-year insulin independence rate for allogenic ICTs is 25-50\% [13-16]. Studies have further confirmed that nearly $15-50 \%$ of the approximated 1-1.5 million islet cells are lost in the isolation process [17], with transplants often times requiring three to four pancreases to achieve euglycemia [18]. Research efforts have accordingly begun focusing on ways to increase the antioxidant response. Particular attention has been given to the Nrf2/Keap1 pathway, a master regulator of antioxidant genes [19].

\section{Nrf2/Keap1 Signaling Pathway}

Nrf2 is a leucine zipper protein that is covalently repressed by its regulator Keap1 in the cytoplasm through ubiquitination [20-22]. Stress induces the separation of these two molecules via modification of the Keap1 cysteine residues, allowing Nrf2 to enter the nucleus and heterodimerize with small Maf Proteins (MafP) (Figure 1). The Nrf2/MafP complex binds to genes which promote the transcription of multiple antioxidant enzymes [23-27]. Yagishita et al. have demonstrated that the Nrf2/Keap1 system plays a critical role in the protection of pancreatic $\beta$-cells from oxidative damage through repressed apoptosis and enhanced proliferation [28]. Nrf2/Keap1 thus promises a potential way of reducing the oxidative damage that occurs in ICT.

Dh404, dimethyl fumarate (DMF), and epigallocatechin gallate (EGCG) are the Nrf2 activators that have been most studied in context of pancreatic inflammation and islet cell transplantation.

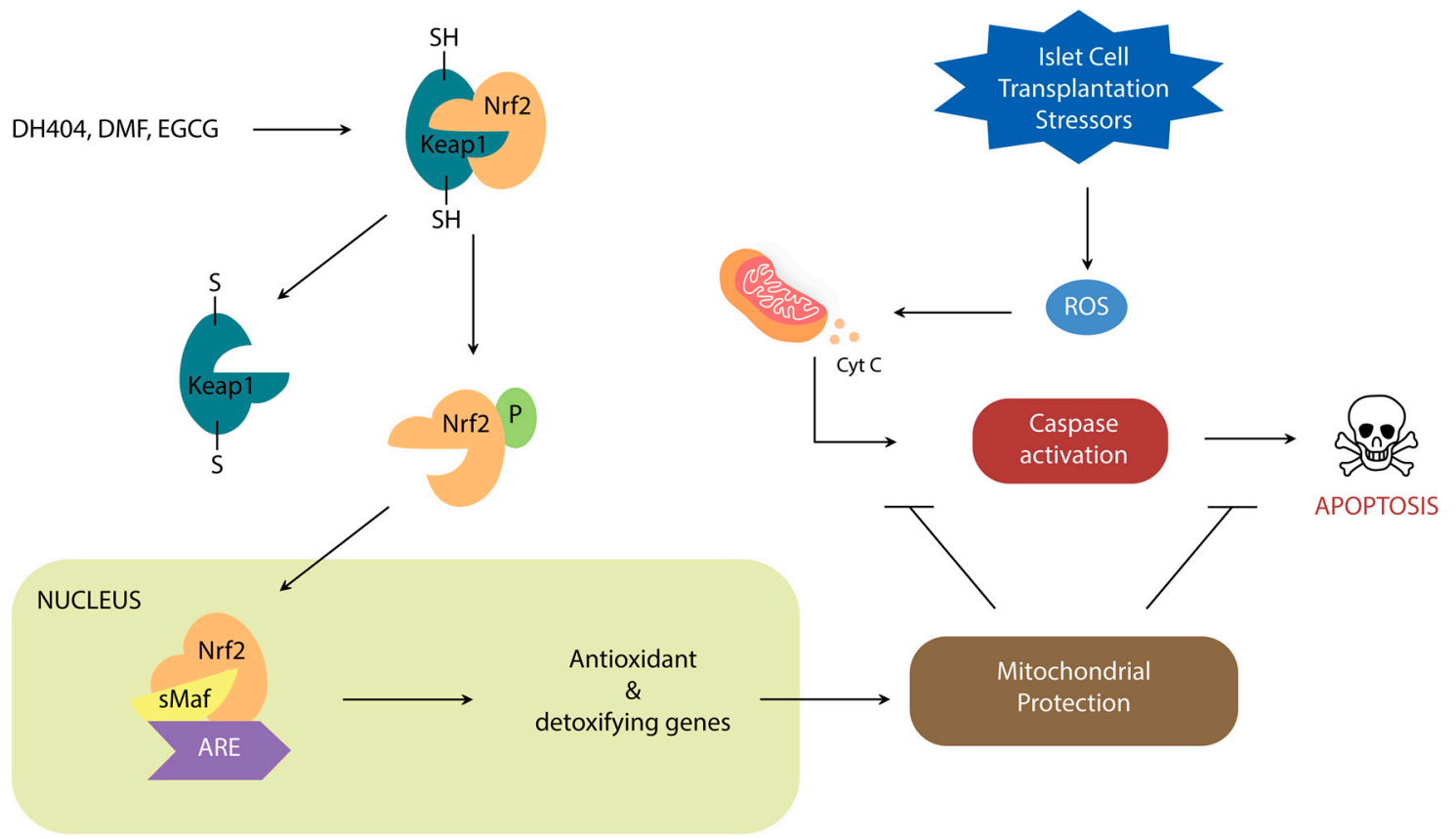

Figure 1. Schematic demonstrating the role of Nrf2/Keap1 signal transduction on oxidative stress regulation.

Nrf2 Activators

Dh404, formally CDDO-9,11-dihydro-trifluoroethyl amide (CDDO-dhTFEA) [29] is a synthetic oleanane triterpenoid (SO) plant derivative used in oriental medicine [30] for anti-inflammatory and anti-tumorigenic purposes [31,32]. Since Yates et al.'s first report of dh404 as a protective agent against aflatoxin-induced tumorigenesis [33], dh404 has been studied in oncology, chronic renal disease, and recently in diseases of the pancreas. As a group, SOs are unique because they are one of the most potent inducers of the Nrf2 pathway with selective induction of phase II detoxifying and antioxidant enzymes [34]. 
Dh404 has proven to be protective in the pathogenesis of acute pancreatitis. Dh404 $(1 \mathrm{mg} / \mathrm{kg})$-treated rats $24 \mathrm{~h}$ before L-arginine $(600 \mathrm{mg} / 100 \mathrm{~g})$-induced pancreatitis showed reductions in inflammatory cells, acinar structural damage, edema, necrosis $(p<0.001)$, and rates of apoptosis $(p<0.05)$ [35]. Malondialdehyde (MDA), which is an indicator of lipid peroxidation, was also reduced $(p<0.05)$ [35]. MDA was further shown to be lower in dh404-cultured cells compared to controls when in $200 \mu \mathrm{M} \mathrm{H}_{2} \mathrm{O}_{2}$ for a 24-h period [35]. Lastly, the effect of dh404 was shown to be temporally dependent, as cells that were incubated with $500 \mathrm{nM}$ dh404 for $1 \mathrm{~h}$ had nearly twice the intranuclear Nrf2 concentration as cells incubated for $30 \mathrm{~min}$. When dh404 treatment was prolonged for $24 \mathrm{~h}$, the presence of anti-oxidant enzymes such as Heme Oxygenase-1 (HO-1), superoxide dismutase (SOD), and catalase (CAT) was recorded [35].

The mechanism of dh404-mediated Nrf2 activation is not yet clear. Ichikawa et al. showed that dh404 is involved in a unique interaction with Cys-151 of Keap1, which under physiological conditions binds Cul3/Rbx1 E3 ligase complex to target Nrf2 ubiquitination and subsequent digestion [36]. On another hand, Li et al. have shown that dh404-mediated Nrf2-activated pathway involves the autophagy of toxic ubiquitinated proteins driven directly by Nrf2 induction, and not by ROS [37]. Because ROS were previously shown [38] to endogenously drive the autophagy process as a defense mechanism to inflammation, these findings suggest that dh404 activates Nrf2 to simultaneously carry out two actions that are not mutually exclusive. Whether this response is entirely due to the Nrf2 or supplemented by an additional pathway activated by dh404 necessitates further investigation.

Dimethyl fumarate, otherwise known as BG-12 or Tecfidera, is a fumarate ester that started out as a recognized anti-carcinogen [39], in the 1990s it was licensed in Germany for treatment of psoriasis, and more recently in 2013 has received approval by the US Food and Drug Administration (FDA) for the treatment of relapsing-remitting multiple sclerosis [40]. Our lab examined the role of DMF as a Nrf2 activator in the setting of pancreatitis [41,42]. Pancreata of rats treated with DMF $(25 \mathrm{mg} / \mathrm{kg}) 24 \mathrm{~h} \mathrm{prior}$ to L-arginine ( $3 \mathrm{~g} / \mathrm{kg}$ )-induced acute pancreatitis showed reductions in the severity of inflammatory cell infiltration, acinar damage, perilobar edema, and cell necrosis $(p<0.001)$ [41]. Similarly, rats that were orally fed DMF (25 mg/kg) prior to and after L-arginine-induced-chronic pancreatitis resulted in improved glucose tolerance, better-preserved tissue architecture (less atrophy, edema, and fatty infiltration) $(p<0.05)$, significantly lower levels of inflammatory markers (myeloperoxidase (MPO) and MDA), and significantly higher expression of antioxidants (i.e., HO-1) [42]. Zhang et al. corroborated similar findings and also demonstrated that animals transplanted with DMF-treated-cells had lower blood glucose $(p<0.01)$ and preserved $\beta$-cell function [43].

Interestingly, and conveniently, DMF has demonstrated to be most efficacious under stressful conditions. In a study performed by Schultheis et al., islet cells from adult mice were cultured for 12-16 $\mathrm{h}$ in $\mathrm{DMF}$, and then for 2 or $48 \mathrm{~h}$ under control or glucolipotoxic conditions $(25 \mathrm{mmol} / \mathrm{L}$ glucose and $100 \mu \mathrm{mol} / \mathrm{L}$ palmitate) [44]. Compared to controls, cells in the glucolipotoxic medium had a decrease in oxidized status, superior insulin secretion, and a higher mitochondrial membrane potential (50 vs. $10 \mu \mathrm{mol} / \mathrm{L}$ ) at $48 \mathrm{~h}$ [44]. While the benefits of DMF in the treatment of inflammatory conditions have been shown to be due to a sundry of anti-inflammatory responses [45-48], the specific mechanism behind Nrf2-activation necessitates further investigation.

Epigallocatechin gallate is a main ingredient of green tea and has been described since the 1990s to have anticarcinogenic, antioxidant, antiangiogenic, antiviral properties, and more recently antidiabetic properties [49-52]. It has been shown to act as a neutralizing agent for ROS, and to have anti-inflammatory effects that have reduced liver fibrosis [53] and even contribute to hepatic regeneration [54].

EGCG has been shown to suppress cytokine-induced pancreatic $\beta$-cell damage in vitro. Pretreatment of RINm5f cells with EGCG $(0-200 \mu \mathrm{g} / \mathrm{mL})$ in presence of proinflammatory cytokines resulted in no cell apoptosis compared to the 55\% that became apoptotic in the absence of EGCG [55]. In fact, the response was noted to be concentration-dependent, with $200 \mu \mathrm{g} / \mathrm{mL}$ EGCG nearly fully blocking the cell death response, abrogating the three-fold increase in $\mathrm{NO}_{2}$ seen in control, 
and completely inhibiting the production of inducible NO synthase (iNOS) [55]. To simulate the inflammatory environment of T1DM in vivo, the authors induced autoimmune diabetes with a $250 \mathrm{mg} / \mathrm{kg}$ streptozotocin (STZ) dose in C57BL/KsJ mice for five consecutive days. In the experimental group, EGCG (100 mg/kg) was administered daily with STZ, and alone for the five days thereafter [56]. Relative to the control group, the EGCG-treated mice had a significantly reduced STZ-induced hyperglycemia, and markedly suppressed iNOS mRNA expression [56].

Despite current evidence that EGCG is an activator of the Nrf2/Keap1 pathway [57], the exact mechanism of how this occurs has yet to be elucidated. There is evidence that the activation involves the mitogen-activated protein kinase (MAPK) cascade [58], electrophilic interactions with the cysteine residues in Keap1 [59], as well as ROS-derived auto-oxidation of EGCG facilitating the release of Nrf2 from its complex [60].

Having introduced the activators with most promise in the setting of pancreatic islet cell transplantation, next we discuss how the Nrf2/Keap1 pathway is a potential target at each step of the transplantation process to protect islet cells from oxidative damage.

\section{Nrf2 Roles in Steps of Islet Transplantation}

\subsection{Nrf2/Keap1: A Target for Pre-Transplant Protection of Islet Cells}

\subsubsection{Isolation: Metabolic Challenges}

Ischemia poses a particular challenge to islet cells because of the cells' low antioxidant defenses and lack of glycogen reserves which prevents them from producing ATP (critical for insulin secretion) [61].

The Nrf2 activator dh404 has shown protective benefits when used during the process of islet cell isolation [62]. Rats that were fed dh $404(0.6 \mathrm{mg} / \mathrm{kg}$ body weight $)$ once daily for three days prior to islet cell isolation had greater islet cell yield $(p<0.05)$ and $\beta$-cell content $(p<0.05)$ compared to vehicle-treated rats [62]. HO-1 upregulation was 10-fold higher and the percentage of apoptotic cells was lower $(p<0.05)$ in treated cells. The same authors have also highlighted that the capacity of the Nrf2 response is dependent on the stress state of the cell [63]. When human islets were treated with $500 \mathrm{nM}$ dh404, a significantly higher proportion of $\beta$-cell survival was observed in the presence of $200 \mu \mathrm{M} \mathrm{H}_{2} \mathrm{O}_{2}$ when compared to those not treated with dh404 (74\% vs. 57\%; $\left.p<0.05\right)$ [63]. Within the cells that survived, they also noted higher levels of nuclear Nrf2 and higher mRNA levels of antioxidant genes like $\mathrm{NAD}(\mathrm{P}) \mathrm{H}$ dehydrogenase [quinone] 1(NQO1), HO-1, and Glutamate-cysteine ligase catalytic subunit (GCLC) [63].

Tetrahydrocurcumin (THC), the final hydrogenated metabolite of curcumin (active ingredient of Curcuma longa L.), has demonstrated very strong antioxidant properties. In an effort to decrease the ROS-mediated islet cell damage prior to transplantation, Kim et al. cultured Balb/c mice islet cells for $24 \mathrm{~h}$ in a THC-supplemented medium, and exposed them to various cytokines [64]. They found that THC-treated cells had 1.3-fold greater glucose sensitivity and produced B-cell lymphoma 2 (BCL2) (antiapoptotic) along with protective caspase proteins [64]. Although at the time of the study it was established that THC increased glutathione (GSH) (a low molecular weight antioxidant), Luo et al. have recently demonstrated that this occurs specifically through the Nrf2/Keap1 pathway [65]. THC causes Nrf2 to translocate into the nucleus, and induce glutamate cysteine ligase (GCL), which is a key determinant of GSH synthesis [66]. Whether THC is a broad antioxidant activator (like dh404) or a more selective one remains to be answered.

\subsubsection{Preservation: Dynamic Temperature Stress on Islet Cells}

Islet cells experience oxidative stress in the freezing and thawing processes that take place during isolation and preparation (Figure 2) [67]. Kanitkar et al. have demonstrated the protective effect of curcumin against extreme temperatures [68]. Isolated mice islet cells were cryopreserved using a standard protocol. These cells were stored in liquid nitrogen for seven days, and thawed rapidly 
from $-196{ }^{\circ} \mathrm{C}$ to $37^{\circ} \mathrm{C}$ [68]. Experimental groups included islets treated with $10 \mu \mathrm{M}$ curcumin during cryopreservation, during the $24 \mathrm{~h}$ post-thaw incubation period, and during both [68]. Inclusion of curcumin at both steps demonstrated increased yield, better morphology and integrity, enhanced basal and stimulated insulin secretion, as well as induction of Hsp70 and HO-1 [68]. While the study did not directly discuss the activation of Nrf2/Keap1, we infer its role given that curcumin is metabolized into THC, a confirmed activator [65].

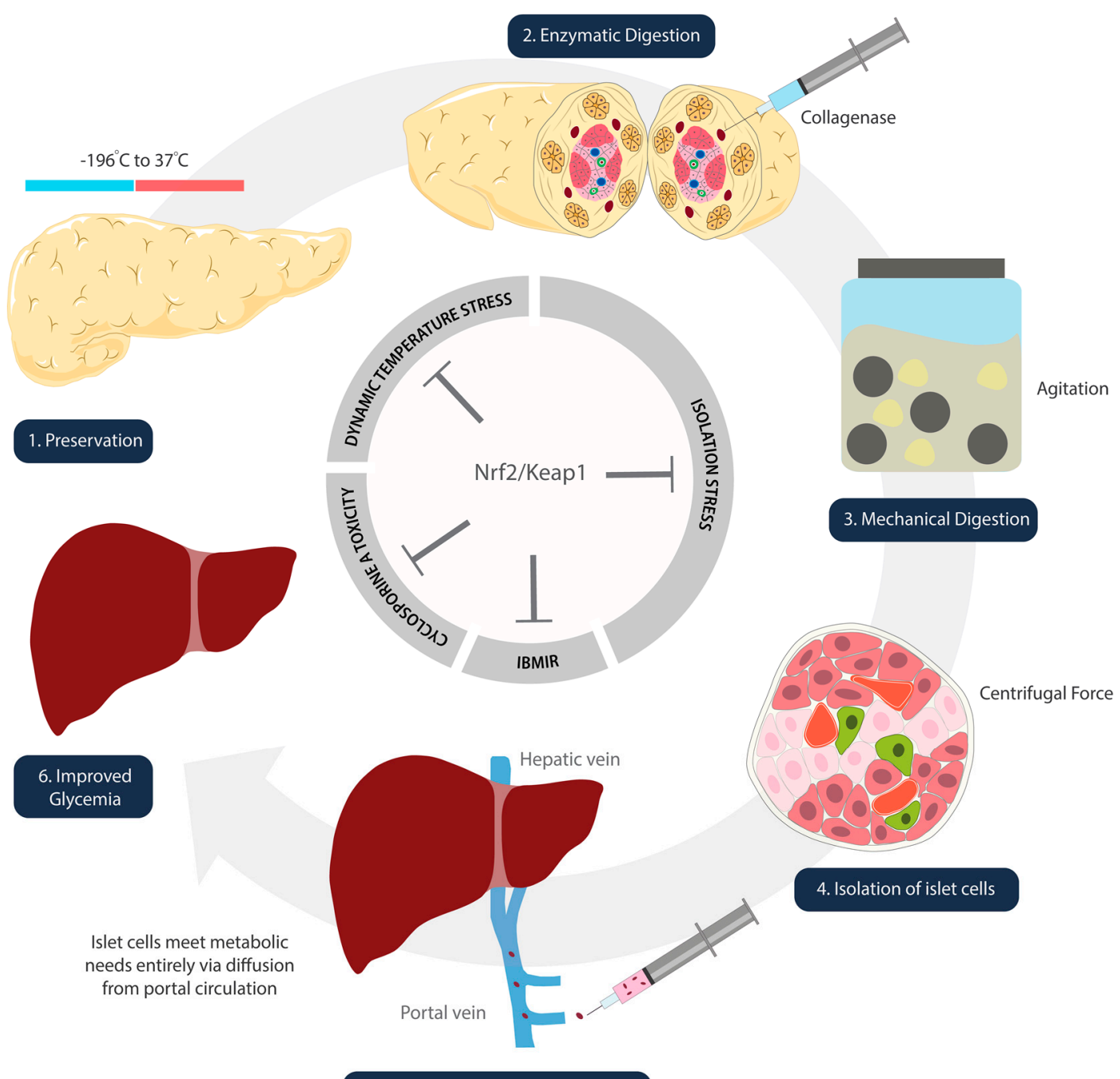

5. Transplantation into portal vein

Figure 2. Schematic illustration denoting steps of islet cell transplantation. Nrf2/Keap1 pathway activation at each of these steps has the potential to ameliorate oxidative damage that occurs as a result of temperature (1), isolation (2-4), reperfusion (5), and immunosuppression side-effect-mediated insults.

The antioxidant response during cold-storage appears to be more protective than oxygenation alone by means of perfluorohexyloctane (F6H8) (a low specific density, oxygen carrier) [69]. Brandhorst et al. may have indirectly shown the involvement of Nrf2/Keap1 in their study where $5 \mathrm{mmol} / \mathrm{L}$ L-glutamine was administered to pig islet cells exposed to warm (30 $\mathrm{min})$ and cold $(3 \mathrm{~h})$ storage [70]. Their hypothesis was based upon previous evidence that glutamine infusion led to formation of intra-islet GSH [71,72]. This was anticipated, as glutamate (deaminated glutamine) is a building block of GSH [73]. While the authors noted a protective effect, they could not explain why glutamine leads to GSH formation specifically at a time of stress. Recently, Sayin et al. have shown that tumor cells hyperactivate the Nrf2 system in order to maintain oxidative homeostasis [74]. In fact, they discovered that tumor cells depend heavily on exogenous glutamine for GSH synthesis [74]. In Brandhorst et al.'s 
study, because glutamine ameliorated the temperature-induced oxidative damage, it is possible that stress upregulated the Nrf2/Keap1 system, which, in effect, increased the demand for the supplied glutamine to synthesize GSH.

\subsubsection{Digestion and Isolation: Chemical and Mechanical Stress on Islet Cells}

Pancreata digestion is required to extract the islet cells from the donor organ. It is a harsh process that involves chemical and mechanical exposures. The islet cells undergo collagenase digestion, agitation in marble glass, and centrifugal forces all while experiencing ischemia and temperature changes (Figure 2) [75]. Although there are no published studies on the direct effect of Nrf2 during pancreatic digestion, one study by Ito et al. indicates the likelihood of its involvement [76]. Pancreata removed from beagle dogs were treated with p38MAPK inhibitor $(\mathrm{P} 38 \mathrm{IH})$ prior to preservation, and were assessed after isolation [76]. The intraductal infusion of P38IH was found to reduce TNF-alpha expression, reduce B-cell apoptosis, and significantly improve the islet cell yield (76). Naidu et al.'s publication one year later elucidated that inhibition of p38MAPK upregulates HO-1 expression via activation of the Nrf2 pathway [77].

\subsection{Nrf2/Keap1: A Target for Post-Transplant Protection of Islet Grafts}

After isolation, the islet cells are injected into the portal vein and distribute heterogeneously in the liver's peripheral branches [78]. It takes approximately 10 days [79] before islet cells establish revascularization, hence the liver is a desirable site due to the constant blood flow which the diffusion-limited islets heavily depend on. While hypoxia is certainly a limiting factor in the survival capacity of the cells once infused, Muthyala et al. showed that even when groups of islet cells were spaced in alginate microcapsules to effectively increase the surface area available for diffusion, neither metabolic activity nor insulin secretion differed significantly from those that were infused as free cells [80]. On the contrary, several groups have shown in both mouse and human models that tissue factor (TF) (expressed on the islet cell membrane) is a major player in the activation and release of a downstream inflammatory cascade that has been coined the immediate blood mediated inflammatory response (IBMIR). IBMIR consists of leukocyte infiltration, complement activation, and thrombosis which has been seen on MRI and positron-emission tomography monitoring to lead to a dramatic reduction of islet cells in the very early peri-transplant period [81-84]. Utilization of Kosinova et al.'s model for in vivo monitoring of liver ischemia in relation to pancreatic islet cell transplants shows promise as a system capable of quantifying the alleviating extent of inflammation [85] with Nrf2/Keap1 activation.

Wada et al. have for the first time shown that EGCG treatment of mouse islets in vivo improves viability and function through the activation the Nrf2 system [86]. To test the response of EGCG in context of cell transplantation, the $100 \mu \mathrm{M}$ EGCG group (concentration found to promote significantly higher cell viability) and a control group were transplanted under the kidney capsule of a $200 \mathrm{mg} / \mathrm{kg}$ STZ-induced diabetic mouse [86]. The cytoprotective effect of EGCG was evident as the ROS production was lower $(p<0.01)$, and the HO-1 mRNA expression of the nuclear-translocated Nrf2-positive cells was higher $(p<0.05)$ in treated cells [86]. Of note, while $100 \mu \mathrm{M}$ was established as the optimal concentration for cell viability and stimulation index, higher concentrations actually proved harmful [86]. The viability and function tests of islets treated with $500 \mu \mathrm{M}$ EGCG were significantly lower than those treated with $100 \mu \mathrm{M}[86]$.

While a majority of the studies on Nrf2 activators have revolved around their protective role in acute and chronic pancreatitis, there are currently no published studies demonstrating their antioxidant effect in context of the immediate reperfusion period after islet cell transplantation. Nevertheless, liver and renal tissue damage secondary to ischemia/reperfusion has been studied in the presence of Nrf2 activator pretreatment, and the results are promising. Our group looked at the effect of DMF pretreatment in rats that were subjected to ischemia for $1 \mathrm{~h}$ and reperfusion for $2 \mathrm{~h}$ [87]. Rats that received orally-administered DMF (25 mg/kg, 2x/day) pretreatment had a significant decrease in levels 
of MDA ( $p=0.0009)$, increased expression of CAT $(p=0.03)$ and Glutamate-Cysteine Ligase Modifier Subunit (GCLM) $(p=0.04)$, decreased neutrophils and markers of inflammation, superior endothelial function and histopathological integrity $(p=0.02)$, and increased ATP levels (apoptosis consumes $\left.\mathrm{NAD}^{+}\right)(p=0.02)[87]$.

Yoon et. al. looked at the effect of sulforaphane pretreatment in Hexokinase 2 (HK2) renal tubular epithelial cells incubated in anaerobic jars at $37^{\circ} \mathrm{C}$, and observed a concentration-dependent benefit [88]. Sulforaphane pretreatment at $20 \mu \mathrm{M}$ improved survival to nearly $93 \%$ (vs. 57\% in control), and increased HO-1, NQO1, Glucocorticoid receptor (GR), and glutathione peroxidase (GPx) mRNA [88]. In vivo pretreatment resulted in significantly depressed $(p<0.01)$ serum creatinine and less macroscopic histological evidence of tubular damage by a factor of 10 relative to untreated controls [88].

The potential application of Nrf2 activators extends beyond the peri-transplant period given evidence of Nrf2's ability to prevent the side-effects caused by immunosuppressants [89]. Our group has previously published that DMF treatment confers renal protection against cyclosporine A nephrotoxicity [89]. Given that transplant patients require long-term immunosuppression with calcineurin inhibitors, we postulate that Nrf2/Keap1 pathway activation plays a critical role in the long-term wellbeing of our patients as well. Future studies are needed to determine whether certain activators will act and be tolerated better as adjuncts to immunosuppressive therapy than others.

\section{Discussion}

Activation of the Nrf2/Keap1 pathway has been demonstrated to confer antioxidant protection in every step of the islet cell transplantation. This is not surprising as the cell is exposed to taxing conditions every step of the way. While dh404, DMF, and EGCG have all been described to have good safety profiles, it is important to note that such is the case when the appropriate dose is used. Many studies have proven the dose-dependent effects of Nrf2 activators. Thus far, dh404 has proven to have an optimal concentration in vivo at $500 \mathrm{nM}$, DMF at $0.25-5 \mu \mathrm{M}$, and EGCG at $100 \mu \mathrm{M}$. When the concentrations are too low or too high relative to their optimum, oxidative stress eventually leads to cell death $[86,90,91]$. Thus, further confirmatory testing at optimal dose of those medications in different applications are necessary prior to human experimentation. Furthermore, the context of application for these Nrf2 activators must be determined as it has been described that they are most effective under stress. Whether the recipient may benefit from Nrf2 activators prophylactically to achieve antioxidant protection prior to transplant would also be worth investigation.

While dh404, DMF, and EGCG are the Nrf2 activators that have been most studied in context of pancreatic inflammation and islet cell transplantation, it is important to note that there are more Nrf2 activators that have been described [92,93]. Establishing a profile index of which activator is most effective and safe would be prudent. Since different activators appear to have unique mechanisms of Nrf2 activation, the simultaneous use of multiple types of activators might result in a summative response. Once the appropriate Nrf2 activator(s) and their optimal dose(s) are confirmed, the next step will be to utilize such activators during recognized oxidative-heavy steps of the peri-transplant process.

\section{Conclusions}

The antioxidant response promulgated by the activation of the Nrf2/Keap1 pathway offers a potential protective mechanism during pancreatic islet cell transplantation. By reducing the amount of oxidative damage islet cells experience in the preservation, isolation, and transplantation process, Nrf2 activators promise a means to enhance viability and henceforth prolong the longevity of transplanted islet cells in Type 1 diabetic recipients.

Author Contributions: H.I. and A.J.L. conceived and designed the study; A.J.L. and H.L. drafted the manuscript; S.L. and H.I. edited and revised the manuscript. All authors have read and agreed to the published version of the manuscript. 
Acknowledgments: Illustrations created by Mariajose Jarrin. The authors received no financial support for the research authorship, and/or publication of this article.

Conflicts of Interest: The authors declare no conflict of interest.

\section{References}

1. Rabinovitch, A.; Suarez-Pinzon, W.L. Cytokines and their roles in pancreatic islet $\beta$-cell destruction and insulin-dependent diabetes mellitus. Biochem. Pharmacol. 1998, 55, 1139-1149. [CrossRef]

2. Eizirik, D.L.; Mandrup-Poulsen, T. A choice of death-the signal-transduction of immune-mediated beta-cell apoptosis. Diabetologia 2001, 44, 2115-2133. [CrossRef]

3. Rewers, M.; Ludvigsson, J. Environmental risk factors for type 1 diabetes. Lancet 2016, 387, $2340-2348$. [CrossRef]

4. Goulden, M.R. The pain of chronic pancreatitis: A persistent clinical challenge. Br. J. Pain 2013, 7, 8-22. [CrossRef]

5. Cdc.gov/Diabetes. Available online: https://www.cdc.gov/diabetes/atlas/countydata/atlas.html (accessed on 30 January 2020).

6. Yadav, D.; Lowenfels, A.B. The epidemiology of pancreatitis and pancreatic cancer. Gastroenterology 2013, 144, 1252-1561. [CrossRef]

7. Raimondi, S.; Lowenfels, A.B.; Morselli-Labate, A.M.; Maisonneuve, P.; Pezzilli, R. Pancreatic cancer in chronic pancreatitis; aetiology, incidence, and early detection. Best Pract. Res. Clin. Gastroenterol. 2010, 24, 349-358. [CrossRef]

8. Choudhary, P.; Rickels, M.R.; Senior, P.A.; Vantyghem, M.C.; Maffi, P.; Kay, T.W.; Keymeulen, B.; Inagaki, N.; Saudek, F.; Lehmann, R.; et al. Evidence-informed clinical practice recommendations for treatment of type 1 diabetes complicated by problematic hypoglycemia. Diabetes Care 2015, 38, 1016-1029. [CrossRef]

9. Jin, S.M.; Kim, K.W. Is islet transplantation a realistic approach to curing diabetes? Korean J. Intern. Med. 2017, 32, 62. [CrossRef]

10. Lei, X.G.; Vatamaniuk, M.Z. Two tales of antioxidant enzymes on $\beta$ cells and diabetes. Antioxid. Redox. Signal. 2011, 14, 489-503. [CrossRef]

11. Lenzen, S.; Drinkgern, J.; Tiedge, M. Low antioxidant enzyme gene expression in pancreatic islets compared with various other mouse tissues. Free Radic. Biol. Med. 1996, 20, 463-466. [CrossRef]

12. Acharya, J.D.; Ghaskadbi, S.S. Islets and their antioxidant defense. Islets 2010, 2, 225-235. [CrossRef]

13. Barton, F.B.; Rickels, M.R.; Alejandro, R.; Hering, B.J.; Wease, S.; Naziruddin, B.; Oberholzer, J.; Odorico, J.S.; Garfinkel, M.R.; Levy, M.; et al. Improvement in outcomes of clinical islet transplantation: 1999-2010. Diabetes Care 2012, 35, 1436-1445. [CrossRef] [PubMed]

14. Bellin, M.D.; Barton, F.B.; Heitman, A.; Harmon, J.V.; Kandaswamy, R.; Balamurugan, A.N.; Sutherland, D.E.; Alejandro, R.; Hering, B.J. Potent induction immunotherapy promotes long-term insulin independence after islet transplantation in type 1 diabetes. Am. J. Transplant. 2012, 12, 1576-1583. [CrossRef] [PubMed]

15. Dunn, T.B.; Kirchner, V.; Bellin, M.D. Beta-cell replacement therapy: Current outcomes and future landscape. Curr. Opin. Organ Transplant. 2015, 20, 681-690. [CrossRef] [PubMed]

16. Kojayan, G.G.; Alexander, M.; Imagawa, D.K.; Lakey, J.R. Systematic review of islet cryopreservation. Islets 2018, 10, 40-49. [CrossRef]

17. Al-Adra, D.P.; Gill, R.S.; Imes, S.; O'Gorman, D.; Kin, T.; Axford, S.J.; Shi, X.; Senior, P.A.; Shapiro, A.J. Single-donor islet transplantation and long-term insulin independence in select patients with type 1 diabetes mellitus. Transplantation 2014, 98, 1007-1012. [CrossRef]

18. Özmen, L.; Ekdahl, K.N.; Elgue, G.; Larsson, R.; Korsgren, O.; Nilsson, B. Inhibition of thrombin abrogates the instant blood-mediated inflammatory reaction triggered by isolated human islets: Possible application of the thrombin inhibitor melagatran in clinical islet transplantation. Diabetes 2002, 51, 1779-1784. [CrossRef]

19. Itoh, K.; Chiba, T.; Takahashi, S.; Ishii, T.; Igarashi, K.; Katoh, Y.; Oyake, T.; Hayashi, N.; Satoh, K.; Hatayama, I.; et al. An Nrf2/small Maf heterodimer mediates the induction of phase II detoxifying enzyme genes through antioxidant response elements. Biochem. Biophys. Res. Commun. 1997, 236, 313-322. [CrossRef]

20. Itoh, K.; Igarashi, K.; Hayashi, N.; Nishizawa, M.; Yamamoto, M. Cloning and characterization of a novel erythroid cell-derived CNC family transcription factor heterodimerizing with the small Maf family proteins. Mol. Cell. Biol. 1995, 15, 4184-4193. [CrossRef] 
21. Itoh, K.; Wakabayashi, N.; Katoh, Y.; Ishii, T.; Igarashi, K.; Engel, J.D.; Yamamoto, M. Keap1 represses nuclear activation of antioxidant responsive elements by Nrf2 through binding to the amino-terminal Neh2 domain. Genes Dev. 1999, 13, 76-86. [CrossRef]

22. Kobayashi, A.; Kang, M.I.; Okawa, H.; Ohtsuji, M.; Zenke, Y.; Chiba, T.; Igarashi, K.; Yamamoto, M. Oxidative stress sensor Keap1 functions as an adaptor for Cul3-based E3 ligase to regulate proteasomal degradation of Nrf2. Mol. Cell. Biol. 2004, 24, 7130-7139. [CrossRef] [PubMed]

23. Ishii, T.; Itoh, K.; Takahashi, S.; Sato, H.; Yanagawa, T.; Katoh, Y.; Bannai, S.; Yamamoto, M. Transcription factor Nrf2 coordinately regulates a group of oxidative stress-inducible genes in macrophages. J. Biol. Chem. 2000, 275, 16023-16029. [CrossRef] [PubMed]

24. Yamazaki, H.; Katsuoka, F.; Motohashi, H.; Engel, J.D.; Yamamoto, M. Embryonic lethality and fetal liver apoptosis in mice lacking all three small Maf proteins. Mol. Cell. Biol. 2012, 32, 808-816. [CrossRef] [PubMed]

25. Hirotsu, Y.; Katsuoka, F.; Funayama, R.; Nagashima, T.; Nishida, Y.; Nakayama, K.; Douglas Engel, J.; Yamamoto, M. Nrf2-MafG heterodimers contribute globally to antioxidant and metabolic networks. Nucleic Acids Res. 2012, 40, 10228-10239. [CrossRef] [PubMed]

26. Halliwell, B.; Whiteman, M. Measuring reactive species and oxidative damage in vivo and in cell culture: How should you do it and what do the results mean? Br. J. Pharmacol. 2004, 142, 231-255. [CrossRef]

27. Sigfrid, L.A.; Cunningham, J.M.; Beeharry, N.; Lortz, S.; Tiedge, M.; Lenzen, S.; Carlsson, C.; Green, I.C. Cytokines and nitric oxide inhibit the enzyme activity of catalase but not its protein or mRNA expression in insulin-producing cells. J. Mol. Endocrinol. 2003, 31, 509-518. [CrossRef]

28. Yagishita, Y.; Fukutomi, T.; Sugawara, A.; Kawamura, H.; Takahashi, T.; Pi, J.; Uruno, A.; Yamamoto, M. Nrf2 protects pancreatic $\beta$-cells from oxidative and nitrosative stress in diabetic model mice. Diabetes 2014, 63, 605-618. [CrossRef]

29. Aminzadeh, M.A.; Reisman, S.A.; Vaziri, N.D.; Khazaeli, M.; Yuan, J.; Meyer, C.J. The synthetic triterpenoid RTA dh404 (CDDO-dhTFEA) restores Nrf2 activity and attenuates oxidative stress, inflammation, and fibrosis in rats with chronic kidney disease. Xenobiotica 2014, 44, 570-578. [CrossRef]

30. Liu, J. Pharmacology of oleanolic acid and ursolic acid. J. Ethnopharmacol. 1995, 49, 57-68. [CrossRef]

31. Nishino, H.; Nishino, A.; Takayasu, J.; Hasegawa, T.; Iwashima, A.; Hirabayashi, K.; Iwata, S.; Shibata, S. Inhibition of the tumor-promoting action of 12-O-tetradecanoylphorbol-13-acetate by some oleanane-type triterpenoid compounds. Cancer Res. 1988, 48, 5210-5215.

32. Huang, M.T.; Ho, C.T.; Wang, Z.Y.; Ferraro, T.; Lou, Y.R.; Stauber, K.; Ma, W.; Georgiadis, C.; Laskin, J.D.; Conney, A.H. Inhibition of skin tumorigenesis by rosemary and its constituents carnosol and ursolic acid. Cancer Res. 1994, 54, 701-708.

33. Yates, M.S.; Kwak, M.K.; Egner, P.A.; Groopman, J.D.; Bodreddigari, S.; Sutter, T.R.; Baumgartner, K.J.; Roebuck, B.D.; Liby, K.T.; Yore, M.M.; et al. Potent protection against aflatoxin-induced tumorigenesis through induction of Nrf2-regulated pathways by the triterpenoid 1-[2-cyano-3-, 12-dioxooleana-1, 9 (11)-dien-28-oyl] imidazole. Cancer Res. 2006, 66, 2488-2494. [CrossRef]

34. Dinkova-Kostova, A.T.; Liby, K.T.; Stephenson, K.K.; Holtzclaw, W.D.; Gao, X.; Suh, N.; Williams, C.; Risingsong, R.; Honda, T.; Gribble, G.W.; et al. Extremely potent triterpenoid inducers of the phase 2 response: Correlations of protection against oxidant and inflammatory stress. Proc. Natl. Acad. Sci. USA 2005, 102, 4584-4589. [CrossRef]

35. Robles, L.; Vaziri, N.D.; Li, S.; Masuda, Y.; Takasu, C.; Takasu, M.; Vo, K.; Farzaneh, S.H.; Stamos, M.J.; Ichii, H. The Synthetic Triterpenoid RTA dh404 (CDDO-dhTFEA) Ameliorates Acute Pancreatitis. Pancreas 2016, 45, 720. [CrossRef]

36. Ichikawa, T.; Li, J.; Meyer, C.J.; Janicki, J.S.; Hannink, M.; Cui, T. Dihydro-CDDO-trifluoroethyl amide (dh404), a novel Nrf2 activator, suppresses oxidative stress in cardiomyocytes. PLoS ONE 2009, 4, e8391. [CrossRef]

37. Li, W.; Wu, W.; Song, H.; Wang, F.; Li, H.; Chen, L.; Lai, Y.; Janicki, J.S.; Ward, K.W.; Meyer, C.J.; et al. Targeting Nrf2 by dihydro-CDDO-trifluoroethyl amide enhances autophagic clearance and viability of $\beta$-cells in a setting of oxidative stress. FEBS Lett. 2014, 588, 2115-2124. [CrossRef]

38. Moore, M.N. Autophagy as a second level protective process in conferring resistance to environmentally-induced oxidative stress. Autophagy 2008, 4, 254-256. [CrossRef]

39. Held, K.D.; Epp, E.R.; Clark, E.P.; Biaglow, J.E. Effect of dimethyl fumarate on the radiation sensitivity of mammalian cells in vitro. Radiat Res. 1988, 115, 495-502. [CrossRef] 
40. Saidu, N.E.; Kavian, N.; Leroy, K.; Jacob, C.; Nicco, C.; Batteux, F.; Alexandre, J. Dimethyl fumarate, a two-edged drug: Current status and future directions. Med. Res. Rev. 2019, 39, 1923-1952. [CrossRef]

41. Robles, L.; Vaziri, N.D.; Li, S.; Takasu, C.; Masuda, Y.; Vo, K.; Farzaneh, S.H.; Stamos, M.J.; Ichii, H. Dimethyl fumarate ameliorates acute pancreatitis in rodent. Pancreas 2015, 44, 441. [CrossRef]

42. Robles, L.; Vaziri, N.D.; Li, S.; Masuda, Y.; Takasu, C.; Takasu, M.; Vo, K.; Farzaneh, S.H.; Stamos, M.J.; Ichii, H. Dimethyl fumarate protects pancreatic islet cells and non-endocrine tissue in L-arginine-induced chronic pancreatitis. PLoS ONE 2014, 9, e107111. [CrossRef] [PubMed]

43. Zhang, W.X.; Zhao, J.H.; Ping, F.M.; Liu, Z.J.; Gu, J.X.; Lu, X.Q. Effect of dimethyl fumarate on rats with chronic pancreatitis. Asian Pac. J. Trop Biomed. 2016, 9, 261-264. [CrossRef] [PubMed]

44. Schultheis, J.; Beckmann, D.; Mulac, D.; Müller, L.; Esselen, M.; Düfer, M. Nrf2 Activation Protects Mouse Beta Cells from Glucolipotoxicity by Restoring Mitochondrial Function and Physiological Redox Balance. Oxid. Med. Cell. Longev. 2019, 2019, 7518510. [CrossRef]

45. Loewe, R.; Holnthoner, W.; Gröger, M.; Pillinger, M.; Gruber, F.; Mechtcheriakova, D.; Hofer, E.; Wolff, K.; Petzelbauer, P. Dimethylfumarate inhibits TNF-induced nuclear entry of NF-kB/p65 in human endothelial cells. J. Immunol 2002, 168, 4781-4787. [CrossRef]

46. Lehmann, J.C.; Listopad, J.J.; Rentzsch, C.U.; Igney, F.H.; von Bonin, A.; Hennekes, H.H.; Asadullah, K.; Docke, W.D. Dimethylfumarate induces immunosuppression via glutathione depletion and subsequent induction of heme oxygenase 1. J. Investig. Dermatol. 2007, 127, 835-845. [CrossRef]

47. Linker, R.A.; Lee, D.H.; Ryan, S.; van Dam, A.M.; Conrad, R.; Bista, P.; Zeng, W.; Hronowsky, X.; Buko, A.; Chollate, S.; et al. Fumaric acid esters exert neuroprotective effects in neuroinflammation via activation of the Nrf2 antioxidant pathway. Brain 2011, 134, 678-692. [CrossRef]

48. Scannevin, R.H.; Chollate, S.; Jung, M.Y.; Shackett, M.; Patel, H.; Bista, P.; Zeng, W.; Ryan, S.; Yamamoto, M.; Lukashev, M.; et al. Fumarates promote cytoprotection of central nervous system cells against oxidative stress via the nuclear factor (erythroid-derived 2)-like 2 pathway. J. Pharmacol. Exp. Ther. 2012, 341, 274-284. [CrossRef]

49. Nakayama, M.; Suzuki, K.; Toda, M.; Okubo, S.; Hara, Y.; Shimamura, T. Inhibition of the infectivity of influenza virus by tea polyphenols. Antivir. Res. 1993, 21, 289-299. [CrossRef]

50. Yang, C.S.; Wang, Z.Y. Tea and cancer. J. Natl. Cancer Inst. 1993, 85, 1038-1049. [CrossRef]

51. Katiyar, S.K.; Mukhtar, H. Tea antioxidants in cancer chemoprevention. J. Cell. Biochem. 1997, 67, 59-67. [CrossRef]

52. Broadhurst, C.L.; Polansky, M.M.; Anderson, R.A. Insulin-like biological activity of culinary and medicinal plant aqueous extracts in vitro. J. Agric. Food Chem. 2000, 48, 849-852. [CrossRef] [PubMed]

53. Higdon, J.V.; Frei, B. Tea catechins and polyphenols: Health effects, metabolism, and antioxidant functions. Crit. Rev. Food Sci. Nutr. 2003, 43, 89-143. [CrossRef]

54. Saito, Y.; Mori, H.; Takasu, C.; Komatsu, M.; Hanaoka, J.; Yamada, S.; Asanoma, M.; Ikemoto, T.; Imura, S.; Morine, Y.; et al. Beneficial effects of green tea catechin on massive hepatectomy model in rats. J. Gastroenterol. 2014, 49, 692-701. [CrossRef]

55. Han, M.K. Epigallocatechin gallate, a constituent of green tea, suppresses cytokine-induced pancreatic $\beta$-cell damage. Exp. Mol. Med. 2003, 35, 136-139. [CrossRef] [PubMed]

56. Song, E.K.; Hur, H.; Han, M.K. Epigallocatechin gallate prevents autoimmune diabetes induced by multiple low doses of streptozotocin in mice. Arch. Pharm. Res. 2003, 26, 559-563. [CrossRef] [PubMed]

57. Shin, J.H.; Jeon, H.J.; Park, J.; Chang, M.S. Epigallocatechin-3-gallate prevents oxidative stress-induced cellular senescence in human mesenchymal stem cells via Nrf2. Int. J. Mol. Med. 2016, 38, 1075-1082. [CrossRef] [PubMed]

58. Andreadi, C.K.; Howells, L.M.; Atherfold, P.A.; Manson, M.M. Involvement of Nrf2, p38, B-Raf, and nuclear factor- $\mathrm{kB}$, but not phosphatidylinositol 3-kinase, in induction of hemeoxygenase-1 by dietary polyphenols. Mol. Pharm. 2006, 69, 1033-1040. [CrossRef]

59. Xu, C.; Li, C.Y.; Kong, A.N. Induction of phase I, II and III drug metabolism/transport by xenobiotics. Arch. Pharm. Res. 2005, 28, 249. [CrossRef]

60. Hong, J.; Lu, H.; Meng, X.; Ryu, J.H.; Hara, Y.; Yang, C.S. Stability, cellular uptake, biotransformation, and efflux of tea polyphenol (-)-epigallocatechin-3-gallate in HT-29 human colon adenocarcinoma cells. Cancer Res. 2002, 62, 7241-7246. 
61. Lablanche, S.; Cottet-Rousselle, C.; Argaud, L.; Laporte, C.; Lamarche, F.; Richard, M.J.; Berney, T.; Benhamou, P.Y.; Fontaine, E. Respective effects of oxygen and energy substrate deprivation on beta cell viability. Biochim. Biophys. Acta Bioenerg. 2015, 1847, 629-639. [CrossRef]

62. Li, S.; Vaziri, N.D.; Masuda, Y.; Hajighasemi-Ossareh, M.; Robles, L.; Le, A.; Vo, K.; Chan, J.Y.; Foster, C.E.; Stamos, M.J.; et al. Pharmacological activation of Nrf2 pathway improves pancreatic islet isolation and transplantation. Cell Transplant. 2015, 24, 2273-2283. [CrossRef] [PubMed]

63. Masuda, Y.; Vaziri, N.D.; Li, S.; Le, A.; Hajighasemi-Ossareh, M.; Robles, L.; Foster, C.E.; Stamos, M.J.; Al-Abodullah, I.; Ricordi, C.; et al. The effect of Nrf2 pathway activation on human pancreatic islet cells. PLoS ONE 2015, 10, e0131012. [CrossRef] [PubMed]

64. Kim, S.S.; Jang, H.J.; Oh, M.Y.; Lee, J.H.; Kang, K.S. Tetrahydrocurcumin enhances islet cell function and attenuates apoptosis in mouse islets. Transplant. Proc. 2018, 50, 2847-2853. [CrossRef]

65. Luo, D.D.; Chen, J.F.; Liu, J.J.; Xie, J.H.; Zhang, Z.B.; Gu, J.Y.; Zhuo, J.Y.; Huang, S.; Su, Z.R.; Sun, Z.H. Tetrahydrocurcumin and octahydrocurcumin, the primary and final hydrogenated metabolites of curcumin, possess superior hepatic-protective effect against acetaminophen-induced liver injury: Role of CYP2E1 and Keap1-Nrf2 pathway. Food Chem. Toxicol. 2019, 123, 349-362. [CrossRef] [PubMed]

66. Lu, S.C. Regulation of glutathione synthesis. Mol. Asp. Med. 2009, 30, 42-59. [CrossRef] [PubMed]

67. Janjic, D.; Andereggen, E.; Deng, S.; Bartley, C.; Buhler, L.; Morel, P.; Wollheim, C.B. Improved insulin secretion of cryopreserved human islets by antioxidant treatment. Pancreas 1996, 13, 166-172. [CrossRef] [PubMed]

68. Kanitkar, M.; Bhonde, R.R. Curcumin treatment enhances islet recovery by induction of heat shock response proteins, Hsp70 and heme oxygenase-1, during cryopreservation. Life Sci. 2008, 82, 182-189. [CrossRef]

69. Brandhorst, H.; Iken, M.; Scott, I.I.I.W.E.; Papas, K.K.; Theisinger, B.; Johnson, P.R.; Korsgren, O.; Brandhorst, D. Quality of isolated pig islets is improved using perfluorohexyloctane for pancreas storage in a split lobe model. Cell Transplant. 2013, 22, 1477-1484. [CrossRef]

70. Brandhorst, H.; Theisinger, B.; Guenther, B.; Johnson, P.R.; Brandhorst, D. Pancreatic L-glutamine administration protects pig islets from cold ischemic injury and increases resistance toward inflammatory mediators. Cell Transplant. 2016, 25, 531-538. [CrossRef]

71. Avila, J.; Barbaro, B.; Gangemi, A.; Romagnoli, T.; Kuechle, J.; Hansen, M.; Shapiro, J.; Testa, G.; Sankary, H.; Benedetti, E.; et al. Intra-ductal glutamine administration reduces oxidative injury during human pancreatic islet isolation. Am. J. Transplant. 2005, 5, 2830-2837. [CrossRef]

72. Avila, J.G.; Tsujimura, T.; Oberholzer, J.; Churchill, T.; Salehi, P.; Shapiro, A.J.; Lakey, J.R. Improvement of pancreatic islet isolation outcomes using glutamine perfusion during isolation procedure. Cell Transplant. 2003, 12, 877-881. [CrossRef] [PubMed]

73. Amores-Sánchez, M.I.; Medina, M.Á. Glutamine, as a precursor of glutathione, and oxidative stress. Mol. Genet. Metab. 1999, 67, 100-105. [CrossRef] [PubMed]

74. Sayin, V.I.; LeBoeuf, S.E.; Singh, S.X.; Davidson, S.M.; Biancur, D.; Guzelhan, B.S.; Alvarez, S.W.; Wu, W.L.; Karakousi, T.R.; Zavitsanou, A.M.; et al. Activation of the NRF2 antioxidant program generates an imbalance in central carbon metabolism in cancer. Elife 2017, 6, e28083. [CrossRef] [PubMed]

75. Kenmochi, T.; Miyamoto, M.; Une, S.; Nakagawa, Y.; Moldovan, S.; Navarro, R.A.; Benhamou, P.Y.; Brunicardi, F.C.; Mullen, Y. Improved quality and yield of islets isolated from human pancreata using a two-step digestion method. Pancreas 2000, 20, 184-190. [CrossRef]

76. Ito, T.; Omori, K.; Rawson, J.; Todorov, I.; Asari, S.; Kuroda, A.; Shintaku, J.; Itakura, S.; Ferreri, K.; Kandeel, F.; et al. Improvement of canine islet yield by donor pancreas infusion with a p38MAPK inhibitor. Transplantation 2008, 86, 321. [CrossRef]

77. Naidu, S.; Vijayan, V.; Santoso, S.; Kietzmann, T.; Immenschuh, S. Inhibition and genetic deficiency of p38 MAPK up-regulates heme oxygenase-1 gene expression via Nrf2. J. Immunol. 2009, 182, 7048-7057. [CrossRef]

78. Naziruddin, B.; Iwahashi, S.; Kanak, M.A.; Takita, M.; Itoh, T.; Levy, M.F. Evidence for instant blood-mediated inflammatory reaction in clinical autologous islet transplantation. Am. J. Transplant. 2014, 14, 428-437. [CrossRef]

79. Vajkoczy, P.; Menger, M.D.; Simpson, E.; Messmer, K. Angiogenesis and vascularization of murine pancreatic islet isografts. Transplantation 1995, 60, 123-127. [CrossRef] 
80. Muthyala, S.; Safley, S.; Gordan, K.; Barber, G.; Weber, C.; Sambanis, A. The effect of hypoxia on free and encapsulated adult porcine islets—an in vitro study. Xenotransplant 2017, 24. [CrossRef]

81. Eich, T.; Eriksson, O.; Lundgren, T. Visualization of early engraftment in clinical islet transplantation by positron-emission tomography. N. Engl. J. Med. 2007, 356, 2754-2755. [CrossRef]

82. Eich, T.; Eriksson, O.; Sundin, A.; Estrada, S.; Brandhorst, D.; Brandhorst, H.; Langstrom, B.; Nilsson, B.; Korsgren, O.; Lundgren, T. Positron emission tomography: A real-time tool to quantify early islet engraftment in a preclinical large animal model. Transplantation 2007, 84, 893-898. [CrossRef] [PubMed]

83. Saudek, F.; Jirák, D.; Girman, P.; Herynek, V.; Dezortová, M.; Kríž, J.; Peregrin, J.; Berková, Z.; Zacharovová, K.; Hájek, M. Magnetic resonance imaging of pancreatic islets transplanted into the liver in humans. Transplantation 2010, 90, 1602-1606. [CrossRef] [PubMed]

84. Jirak, D.; Kriz, J.; Strzelecki, M.; Yang, J.; Hasilo, C.; White, D.J.; Foster, P.J. Monitoring the survival of islet transplants by MRI using a novel technique for their automated detection and quantification. MAGMA 2009, 22, 257-265. [CrossRef]

85. Kosinova, L.; Patikova, A.; Jirak, D.; Galisova, A.; Vojtiskova, A.; Saudek, F.; Kriz, J. A novel model for in vivo quantification of immediate liver perfusion impairment after pancreatic islet transplantation. Islets 2019, 11, 129-140. [CrossRef]

86. Wada, Y.; Takata, A.; Ikemoto, T.; Morine, Y.; Imura, S.; Iwahashi, S.; Saito, Y.; Shimada, M. The protective effect of epigallocatechin 3-gallate on mouse pancreatic islets via the Nrf2 pathway. Surg. Today 2019, 49, 536-545. [CrossRef] [PubMed]

87. Takasu, C.; Vaziri, N.D.; Li, S.; Robles, L.; Vo, K.; Takasu, M.; Pham, C.; Farzaneh, S.H.; Shimada, M.; Stamos, M.J.; et al. Treatment with dimethyl fumarate ameliorates liver ischemia/reperfusion injury. World J. Gastroenterol. 2017, 23, 4508. [CrossRef] [PubMed]

88. Yoon, H.Y.; Kang, N.I.; Lee, H.K.; Jang, K.Y.; Park, J.W.; Park, B.H. Sulforaphane protects kidneys against ischemia-reperfusion injury through induction of the Nrf2-dependent phase 2 enzyme. Biochem. Pharmacol. 2008, 75, 2214-2223. [CrossRef]

89. Takasu, C.; Vaziri, N.D.; Li, S.; Robles, L.; Vo, K.; Takasu, M.; Pham, C.; Liu, S.; Farzaneh, S.H.; Foster, C.E., 3rd; et al. Treatment with dimethyl fumarate attenuates calcineurin inhibitor-induced nephrotoxicity. Transplantation 2015, 99, 1144. [CrossRef]

90. Saidu, N.E.; Noé, G.; Cerles, O.; Cabel, L.; Kavian-Tessler, N.; Chouzenoux, S.; Bahuaud, M.; Chéreau, C.; Nicco, C.; Leroy, K.; et al. Dimethyl fumarate controls the NRF2/DJ-1 axis in cancer cells: Therapeutic applications. Mol. Cancer Ther. 2017, 16, 529-539. [CrossRef]

91. Saidu, N.E.; Bretagne, M.; Mansuet, A.L.; Just, P.A.; Leroy, K.; Cerles, O.; Chouzenoux, S.; Nicco, C.; Damotte, D.; Alifano, M.; et al. Dimethyl fumarate is highly cytotoxic in KRAS mutated cancer cells but spares non-tumorigenic cells. Oncotarget 2018, 9, 9088. [CrossRef]

92. Robledinos-Antón, N.; Fernández-Ginés, R.; Manda, G.; Cuadrado, A. Activators and inhibitors of NRF2: A review of their potential for clinical development. Oxid. Med. Cell. Longev. 2019, 9372182. [CrossRef]

93. Bhakkiyalakshmi, E.; Sireesh, D.; Rajaguru, P.; Paulmurugan, R.; Ramkumar, K.M. The emerging role of redox-sensitive Nrf2-Keap1 pathway in diabetes. Pharm. Res. 2015, 91, 104-114. [CrossRef] [PubMed]

(C) 2020 by the authors. Licensee MDPI, Basel, Switzerland. This article is an open access article distributed under the terms and conditions of the Creative Commons Attribution (CC BY) license (http://creativecommons.org/licenses/by/4.0/). 